\title{
Irrigation water: Its influence on the quality of soils in Amravati district, Maharashtra
}

\author{
Deepak G. Padekar and T. Bhattacharyya
}

MEMBERS OF RESEARCH FORUM:

Corresponding author : Deepak G. Padekar, Department of Soil Science and Agricultural Chemistry, Shri Shivaji College of Agriculture, Amravati (M.S.) India Email: dgpadekar@gmail.com

Co-authors :

T. Bhattacharyya, Dr. Balasaheb Sawant Konkan Krishi Vidyapeeth, Dapoli (M.S.) India
Received : 05.04.2018; Revised : 02.05.2018; Accepted : 16.05.2018

\section{Summary}

Poor quality of both surface and groundwater is a limiting factor for the irrigation of many black soil areas of the Purna Valley, Maharashtra. The present study is a humble effort to flag some of the concerns of these valley raised by the farmers in Amravati district representing the Vidarbha region of Maharashtra. Irrigation sources are river, canal and predominantly wells in the study area. Samples of irrigation water and soils were collected and analysed from four tehsils of Amravati district, Vidarbha, Maharashtra to assess the quality of irrigation water and its impact on black soils. Soil samples (Shirala-Amravati, Darapur- Daryapur, Wathoda- Bhatkuli and Temburkheda- Warud) were analysed to study the influence of irrigation water on soil characteristics. It was observed that the water used for irrigation in Shirala soil is in the class C3S2 with sodium adsorption ratio (SAR) value $\sim 12$, electrical conductivity (EC) $1.8 \mathrm{dSm}^{-1}$ and $\mathrm{Na}^{+} 14.0 \mathrm{mmol}_{\mathrm{c}}{ }^{-1}$ which increased the $\mathrm{EC}$ of soils. The higher concentration of $\mathrm{Na}^{+}$and $\mathrm{Mg}^{2+}$ ions is responsible for drainage impairment. The irrigation water of Wathoda (C4S1) increased EC values of irrigated soils. The reduced saturated hydraulic conductivity (sHC) in irrigated soils as compared to unirrigated soils is attributed to the higher concentration of sodium. The water used for irrigation in Temburkheda and Darapur are similar in quality (C3S1). The soils of Darapur experienced significant increase in EC as compared to Temburkheda soils. This was also associated with decrease in the values of soil drainage (sHC :0.14-0.17 $\left.\mathrm{cmh}^{-1}\right)$ in the Darapur soils. Moreover, exchangeable as well as water soluble $\mathrm{Na}^{+}, \mathrm{Mg}^{++}$cations and EC also increased in the upper layers of the irrigated soils due to application of poor quality irrigation water. This caused deterioration of the soil quality. With the help of temporal datasets of soils the effect of irrigation water on soil properties was assessed. The soils which were rainfed showed improved condition in terms of several physical and chemical properties; however, the soils when irrigated with poor quality water brought several problems in soils in terms of physical and chemical properties. Immediate measures are necessary in the study area.

Key words : Irrigation water, Influence, Quality of soils

How to cite this article : Padekar, Deepak G. and Bhattacharyya, T. (2018). Irrigation water: Its influence on the quality of soils in Amravati district, Maharashtra. Asian J. Soil Sci., 13 (1) : 19-29: DOI : 10.15740/HAS/AJSS/13.1/19-29. Copyright@ 2018: Hind Agri-Horticultural Society. 